\title{
Effect of Curing Methods on the Compressive Strength of Kenaf Stabilised 'Green' Lateritic Mortar
}

\author{
Temitope Oyeniran $^{1, *}$, Olayinka Omotosho², Babatunde Olanrewaju ${ }^{1}$ \\ ${ }^{1}$ Department of Agricultural and Environmental Engineering, Obafemi Awolowo University, Ile-Ife, Nigeria \\ ${ }^{2}$ Agricultural and Environmental Engineering Unit, Institute of Agricultural Research and Training, Obafemi Awolowo University, Moor \\ Plantation, Ibadan, Nigeria
}

Email address:

topeoyeniran@yahoo.com (T. Oyeniran)

${ }^{*}$ Corresponding author

\section{To cite this article:}

Temitope Oyeniran, Olayinka Omotosho, Babatunde Olanrewaju. Effect of Curing Methods on the Compressive Strength of Kenaf Stabilised 'Green' Lateritic Mortar. Journal of Civil, Construction and Environmental Engineering. Vol. 3, No. 3, 2018, pp. 78-82.

doi: $10.11648 /$ j.jccee.20180303.14

Received: April 13, 2018; Accepted: May 7, 2018; Published: August 16, 2018

\begin{abstract}
The study considered the effects of curing methods on the compressive strength of kenaf stabilised lateritic mortar at 1:5 and 1:10 cement-aggregate mix ratio. Composition of the mortar for each of the cement mix ratios was also substituted with kenaf fibres at $0,0.5,1.0,1.5,2.0$ and $2.5 \%$ by weight. The effects of these factors on compressive strength of the green mortar revealed that at 1:5 cement mix, the values obtained from 28 days compressive strength of water cured samples revealed that, the kenaf replacement level should not exceed $1.0 \%$ while for air curing it should not exceed $1.5 \%$ in order to satisfy the ASTM C279 standard for O type mortar. However at 28 days the compressive strength of the samples at 1:10 cement mix did not meet the ASTM C279 standard for $\mathrm{O}$ and $\mathrm{N}$ type mortar thus indicating that binder strength was inadequate. In general the failure in kenaf fibrous mortar samples was observed to have been slow and gradual, compared to the instantaneous nature of failure observed in the pure cement-aggregate samples.
\end{abstract}

Keywords: Compressive Strength, Curing Days, Kenaf Content, Laterite, Mix Ratio

\section{Introduction}

As the Nigerian population keeps increasing, there is an accompanying dire need for buildings. This has led to the increasing demand for building materials which are now expensive [1]. [2, 3] reported that the building industry is suffering from shortage and high cost of building materials. According to [4], housing programmes in Nigeria and other developing countries of the world are being executed without the use of traditional building materials. This has resulted in the high cost of building and the non-realization of governmental housing objectives. The cost of building materials unilaterally affects housing. The higher the cost of building materials, the higher the cost of housing construction and the fewer the number of people who can afford their desired houses [5]. According to [6], one of the suggestions for cutting down conventional building material costs has been the sourcing, development and use of alternative, non-conventional local construction materials.

Lateritic soils are widely used as a building material in Nigeria and many other developing countries of the world. In addition to Mud walls, brick masonry (dried or burnt type), buildings are made from lateritic soils in both rural and urban areas of the country, Nigeria. According to [7], the use of laterite to replace sand component of concrete either wholly or partially, is becoming widespread among the low income earners for building construction. The utilization of laterites enables the provision of low-cost houses and other rural infrastructures. Also, studies have been reported on fibrereinforced laterized concrete by [8]. Wire, grass and kenaf rope were used to improve shear and tensile strength. When mortar is reinforced with biological fibre materials it is referred to as 'green mortar' in some quarters.

Kenaf (Hibiscus cannabinus) fibre has recently gained 
popularity as a biological reinforcement [9-12]. This is due to its renewability - ease of cultivation and high strength [13]. Utilisation of local materials is an important step to sustainable construction to reduce transportation cost, save embodied energy, and protect the environment [14]. Thus, an understanding of how locally available materials can be adapted for buildings and at the same time lower cost and raise standards without material increase in cost is necessary [15].

This study was limited to the use of laterite, kenaf and cement for the production of test specimens used for compressive strength, in the Department of Agricultural and Environmental Engineering, Obafemi Awolowo University, Ile-Ife, Osun State, Nigeria. The main objective was to determine the effects of mix ratio, kenaf content, curing days and method on the compressive strength of the specimens. Findings from this study could supply knowledge on effectiveness or otherwise of 'green material' in form of kenaf fibre in production of composite mortars. On the other hand, this study could provide information on environmentally sustainable practices which will help to reduce the usage of steel, a non-renewable material in construction of light weight structures.

\section{Materials and Methods}

The fine aggregate (lateritic soil) used for the study was collected from a burrowed pit at Ajebanlele area, along IfeIbadan express road, Ile-ife, Osun state in Nigeria. The reinforcement (kenaf bast fibres) was procured from the Kenaf Improvement Unit, Institute of Agricultural Research and Training (IAR\&T), Obafemi Awolowo University, Moor Plantation, Ibadan, Nigeria. The binder (OPC) was purchased from a building materials market located at Sabo area in IleIfe and potable water from the Department of Agricultural and Environmental Engineering, Obafemi Awolowo University Ile-Ife.

The sieve analysis for the lateritic soil was carried out using the mechanical sieve in the soil and water laboratory in the Department of Agricultural and Environmental Engineering. The machine was operated three times for ten minutes. A constant homogenous soil sample (500 g) was used in each case and their average was used in computations. The result is shown in Table 1. To remove debris, stones and obtain a fine soil, only particles passing through sieve number 4 (4.75 $\mathrm{mm})$ was used.

Table 1. Sieve analysis of the soil used.

\begin{tabular}{|c|c|c|c|c|c|c|c|c|}
\hline \multirow{2}{*}{$\begin{array}{l}\text { Sieve Size } \\
(\mathrm{mm})\end{array}$} & \multirow{2}{*}{$\begin{array}{l}\text { Mass of } \\
\text { Sieve (g) }\end{array}$} & \multicolumn{3}{|c|}{ Mass of Soil Retained (g) } & \multirow{2}{*}{$\begin{array}{l}\text { Average Mass of } \\
\text { Soil Retained (g) }\end{array}$} & \multirow{2}{*}{$\begin{array}{l}\text { Percentage } \\
\text { Retained }\end{array}$} & \multirow{2}{*}{$\begin{array}{l}\text { Cumulative } \\
\text { percentage retained }\end{array}$} & \multirow{2}{*}{$\begin{array}{l}\text { Percentage } \\
\text { Finer }\end{array}$} \\
\hline & & $\mathbf{M}_{1}$ & $\mathbf{M}_{2}$ & $\mathbf{M}_{3}$ & & & & \\
\hline 4.75 & 518.29 & 6.67 & 16.89 & 2.37 & 8.64 & 1.74 & 1.74 & 98.26 \\
\hline 1.18 & 394.65 & 65.13 & 64.33 & 58.41 & 62.62 & 12.59 & 14.33 & 85.67 \\
\hline 0.841 & 375.09 & 46.09 & 47.49 & 45.81 & 46.46 & 9.34 & 23.67 & 76.33 \\
\hline 0.420 & 353.47 & 163.9 & 169.38 & 163.00 & 165.43 & 33.27 & 56.94 & 43.06 \\
\hline 0.210 & 314.28 & 143.58 & 131.06 & 143.30 & 139.31 & 28.01 & 84.95 & 15.05 \\
\hline 0.150 & 288.09 & 29.98 & 30.36 & 32.08 & 30.81 & 6.20 & 91.15 & 8.85 \\
\hline Receiver & 286.76 & 14.21 & 12.81 & 16.50 & 14.51 & 02.92 & 100.0 & 0.00 \\
\hline
\end{tabular}

The batching was done by weight and two mix ratios, 1:5 and 1:10 were adopted as recommended by [16 and 17]. These mix ratios were kept constant throughout. The water/cement ratio was determined using the slump test. The water cement ratio was 0.26 and 0.22 for $1: 5$ and $1: 10 \mathrm{mix}$ ratios respectively. This was to enhance mix workability as kenaf bast fibres reduce workability. The kenaf bast fibre was cut to $30 \mathrm{~mm}$ length size. The mixing followed a chronological order; laterite and cement, water then finally, fibres. Kenaf bast fibre used for the experiment were added at the rate of $0 \%, 0.5 \%, 1 \%, 1.5 \%, 2.0 \%$, and $2.5 \%$ of the weight of specimens used in this study.

A cast tray consisting of 25 number, $100 \mathrm{~mm} \times 100 \mathrm{~mm}$ cube units was used to produce test specimens (Figure 1). After twenty four hours, the specimens were removed from the casts. Each specimen was produced in triplicates. Decasting was done within 24 hours and curing of the specimens in water (Figure 2) and air (Figure 3) respectively started. Specimens were cured for 7, 14, 21, and 28 days.

The bearing surface of the testing machine was cleaned, specimens were then physically inspected for visible signs of cracks or any damage then selected at random and aligned centrally on the base of the universal testing machine. The load was applied to the side perpendicular to the finishing surface of the specimen. The load at failure was then recorded.

The compressive strength was calculated thus,

$$
C_{s}=\frac{P}{A}
$$

Where;

$C_{s}=$ compressive strength $\left(\mathrm{N} / \mathrm{mm}^{2}\right)$

$P=$ compressive load at failure $(\mathrm{N})$ and

$A=$ surface area of specimen before failure $\left(\mathrm{mm}^{2}\right)$

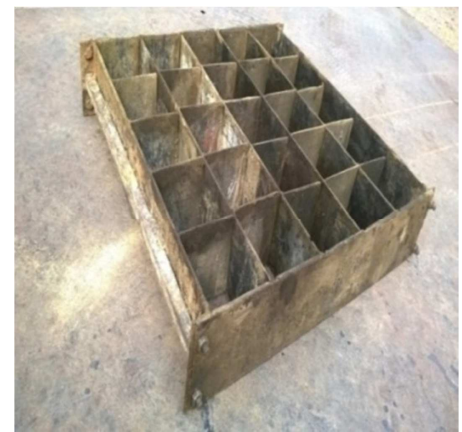

Figure 1. $100 \mathrm{~mm} \times 100 \mathrm{~mm}$ cast tray used in producing the test cubes. 


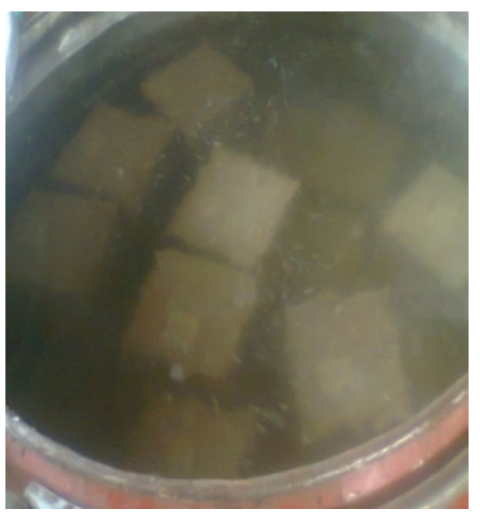

Figure 2. Curing cubes in water.

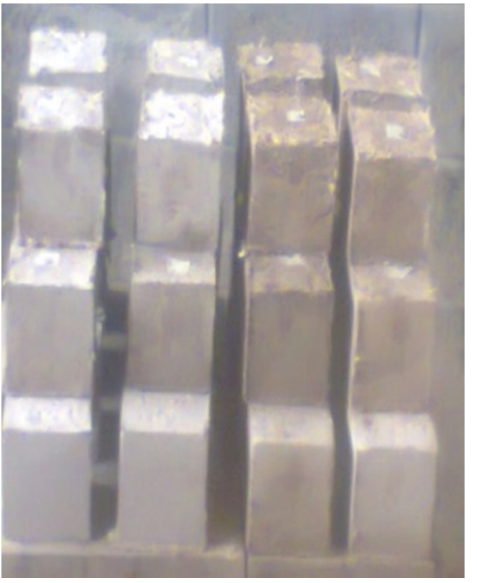

Figure 3. Curing cubes in air.

\section{Results and Discussion}

\subsection{Compressive Strength of 1:5 Cement Mix Mortar}

Results obtained from the study (Table 2) revealed that at 1:5 cement mix ratio the compressive strength of the cubes increased with length of curing in water and air for the $0 \%$ replacement level as observed by [18], the 0.5 and $1.0 \%$ kenaf replacement levels were also observed to have also offered similar results thus implying that the kenaf replacements at these levels had no.

Noticeable effect on compressive strength of the mortar samples. The trend was however different for air cured samples with 2.0 and $2.5 \%$ kenaf replacement levels as the increment in compressive strength with length of curing was observed to have nosedived after 21 days curing this may have been due to the pronounced shrinkage of the kenaf materials as the cubes dried thereby leading to reduction in weight and higher loss of moisture (table 3 ) as well as formation of pores within the interstices of the concrete samples thereby increasing failure rate. Water cured samples were also observed to have followed the same trend after 21 days as observed in the air cured samples, however the loss of compressive strength in this case may have been due to reduction in the stability of the embedded biological material (kenaf) as a result of the presence of moisture which could cause the onset of decomposition. Statistically the result shows that the effect of the kenaf content was significant $(p \leq 0.05)$ for both the air and water cured mortar samples.

Table 2. Comparison of Compressive Strength $\left(\mathrm{N} / \mathrm{mm}^{2}\right)$ for water and air cured specimens for 1:5 cement mix ratios at different curing days interval.

\begin{tabular}{|c|c|c|c|c|c|c|c|c|}
\hline & & & \multicolumn{6}{|c|}{ Kenaf Content $(\%)^{*}$} \\
\hline & & & 0.0 & 0.5 & 1.0 & 1.5 & 2.0 & 2.5 \\
\hline \multirow{7}{*}{$\begin{array}{l}\text { Curing Days } \\
\text { and Medium }\end{array}$} & \multirow{2}{*}{7 Days } & Air & $3.06^{\mathrm{a}}$ & $2.67^{\mathrm{a}}$ & $1.29^{\mathrm{b}}$ & $0.71^{\mathrm{b}}$ & $0.57^{\mathrm{c}}$ & $0.38^{c}$ \\
\hline & & Water & $2.50^{\mathrm{a}}$ & $2.03^{\mathrm{b}}$ & $1.18^{\mathrm{b}}$ & $0.50^{\mathrm{c}}$ & $0.21^{\mathrm{c}}$ & $0.18^{\mathrm{c}}$ \\
\hline & \multirow{2}{*}{14 Days } & Air & $3.55^{\mathrm{a}}$ & $3.33^{\mathrm{ab}}$ & $1.70^{\mathrm{b}}$ & $1.27^{\mathrm{b}}$ & $0.62^{\mathrm{c}}$ & $0.57^{\mathrm{c}}$ \\
\hline & & Water & $2.80^{\mathrm{a}}$ & $1.65^{\mathrm{ab}}$ & $1.13^{\mathrm{ab}}$ & $0.55^{\mathrm{b}}$ & $0.50^{\mathrm{b}}$ & $0.42^{c}$ \\
\hline & 21 Days & Air & $5.37^{\mathrm{a}}$ & $3.67^{\mathrm{b}}$ & $1.92^{\mathrm{b}}$ & $1.48^{\mathrm{c}}$ & $0.81^{\mathrm{c}}$ & $0.41^{\mathrm{c}}$ \\
\hline & \multirow{2}{*}{ 2.8 Days } & Air & $6.03^{\mathrm{a}}$ & $5.67^{\mathrm{b}}$ & $4.00^{b}$ & $2.57^{\mathrm{b}}$ & $1.50^{\mathrm{b}}$ & $0.70^{\mathrm{b}}$ \\
\hline & & Water & $5.30^{\mathrm{a}}$ & $4.13^{\mathrm{a}}$ & $3.10^{\mathrm{b}}$ & $2.17^{\mathrm{b}}$ & $2.75^{b}$ & $2.68^{\mathrm{c}}$ \\
\hline
\end{tabular}

* Superscripts with the same letters along the row are not significantly different at $p \leq 0.05$.

Table 3. Weight variation of cubes with change in curing days and kenaf content at 1:5 cement mix ratio.

\begin{tabular}{lllll}
\hline \multirow{2}{*}{$\begin{array}{l}\text { Kenaf } \\
\text { Content (\%) }\end{array}$} & Cube weight $(\mathrm{g})$ & \\
\cline { 2 - 5 } & 7 Days & 14 Days & 21Days & 28 Days \\
\hline 0 & 1892.47 & 1874.12 & 1869.22 & 1843.33 \\
0.5 & 1832.54 & 1799.67 & 1789.31 & 1768.67 \\
1.0 & 1801.98 & 1778.87 & 1762.10 & 1728.67 \\
1.5 & 1697.21 & 1654.32 & 1648.45 & 1607.33 \\
2.0 & 1625.07 & 1587.65 & 1552.32 & 1508.67 \\
2.5 & 1601.43 & 1560.21 & 1522.23 & 1431.00 \\
\hline
\end{tabular}

After 7 days of air curing it was observed that the control and $0.5 \%$ kenaf replacement samples were the only ones that had compressive strengths greater than standards as specified by [19] for mortar type $O$ while none of the kenaf replacement samples met the same standard. At 28 days air curing the compressive strength of mortar samples at $0,0.5$, 1.0 and 1.5 kenaf replacement levels were observed to have conformed to [19] standard for minimum compressive strengths for mortar type $O$. The air cured samples with kenaf replacement levels 0 f 0 and 0.5 were also observed to have been above the minimum requirement for mortar type $\mathrm{N}$ according to [19] standard. This reveals that for air cure samples kenaf replacement levels should not exceed $1.5 \%$. The water cured samples at $0,0.5$ and 1.0 kenaf replacement levels were observed to have passed the [19] standard for 
mortar type $\mathrm{O}$ while none of the kenaf replacement samples passed the [19] standard for mortar type N. This result reveals that for water curing the kenaf replacement level should not exceed $1.0 \%$ at 1:5 cement mix ratio.

\subsection{Compressive Strength of 1:10 Cement Mix Mortar}

The compressive strength (Table 4) of the samples were also observed to have followed the same trend as those of 1:5 mix however, a comparison of the values of observed compressive strength with approved standards showed that mortar specimens at cement mix ratio 1:10 were all below [19] standard for both $\mathrm{N}$ and $\mathrm{O}$ mortar types for both water and air cured samples. The samples were also observed to have presented a much lighter weight (Table 5) than what was obtained for the 1:5 cement mix samples (Table 3), this was as a result of a combination of difference in densities resulting from cement-aggregate composition and the kenaf replacement in the mass of the samples. This variation in weight/density of biological material stabilised cement mortar agrees with findings made by [20] on cow dung stabilised earth bricks.

In general the failure in kenaf fibrous mortar samples was observed to have been slow and gradual, compared to the instantaneous nature of failure observed in the control or $0 \%$ kenaf replacement samples at both 1:5 and 1:10 cement mix ratios. This implies that the fibrous mortar composite exhibited greater ductility and in essence higher ability to sustain load for a considerable length of time before failure despite the reduction in compressive strength it causes in the mortar. This also agrees with findings made by [21].

Table 4. Comparison of Compressive Strength $\left(\mathrm{N} / \mathrm{mm}^{2}\right)$ for water and air cured specimens for 1:10 cement mix ratios at different curing days interval.

\begin{tabular}{|c|c|c|c|c|c|c|c|c|}
\hline & & & \multicolumn{6}{|c|}{ Kenaf Content (\%)* } \\
\hline & & & 0.0 & 0.5 & 1.0 & 1.5 & 2.0 & 2.5 \\
\hline \multirow{7}{*}{$\begin{array}{l}\text { Curing Days } \\
\text { and Medium }\end{array}$} & \multirow{2}{*}{7 Days } & Air & $0.76^{\mathrm{a}}$ & $0.37^{\mathrm{b}}$ & $0.36^{\mathrm{b}}$ & $0.30^{\mathrm{b}}$ & $0.19^{c}$ & $0.14^{\mathrm{c}}$ \\
\hline & & Water & $0.34^{\mathrm{a}}$ & $0.52^{\mathrm{b}}$ & $0.65^{\mathrm{b}}$ & $0.25^{\mathrm{c}}$ & $0.06^{\mathrm{c}}$ & $0.05^{\mathrm{c}}$ \\
\hline & \multirow{2}{*}{14 Days } & Air & $0.91^{\mathrm{a}}$ & $0.90^{\mathrm{a}}$ & $0.36^{\mathrm{b}}$ & $0.23^{\mathrm{c}}$ & $0.25^{\mathrm{c}}$ & $0.08^{\mathrm{c}}$ \\
\hline & & Water & $0.33^{\mathrm{a}}$ & $0.34^{\mathrm{a}}$ & $0.45^{\mathrm{a}}$ & $0.25^{\mathrm{b}}$ & $0.05^{\mathrm{b}}$ & $0.00^{\mathrm{c}}$ \\
\hline & 21 Days & Air & $1.54^{\mathrm{a}}$ & $0.93^{\mathrm{a}}$ & $0.37^{\mathrm{b}}$ & $0.18^{\mathrm{b}}$ & $0.10^{\mathrm{b}}$ & $0.03^{\mathrm{c}}$ \\
\hline & \multirow{2}{*}{.8 Days } & Air & $1.10^{\mathrm{a}}$ & $1.20^{\mathrm{a}}$ & $0.73^{\mathrm{a}}$ & $0.23^{\mathrm{b}}$ & $0.17^{b}$ & $0.08^{\mathrm{b}}$ \\
\hline & & Water & $2.20^{\mathrm{a}}$ & $1.83^{\mathrm{a}}$ & $1.53^{\mathrm{b}}$ & $1.07^{\mathrm{b}}$ & $1.00^{\mathrm{b}}$ & $0.87^{\mathrm{c}}$ \\
\hline
\end{tabular}

* Superscripts with the same letters along the row are not significantly different at $p \leq 0.05$.

Table 5. Weight variation of cubes with change in curing days and kenaf content at 1:10 cement mix ratio.

\begin{tabular}{lllll}
\hline \multirow{2}{*}{$\begin{array}{l}\text { Kenaf } \\
\text { Content (\%) }\end{array}$} & \multicolumn{4}{l}{ Cube weight (g) } \\
\cline { 2 - 5 } 7 Days & 14 Days & 21Days & 28 Days \\
\hline 0 & 1921.33 & 1897.23 & 1875.21 & 1853.00 \\
0.5 & 1879.98 & 1842.98 & 1810.31 & 1784.33 \\
1.0 & 1732.65 & 1698.78 & 1674.76 & 1642.67 \\
1.5 & 1596.76 & 1562.22 & 1501.54 & 1477.33 \\
2.0 & 1564.32 & 1532.87 & 1498.98 & 1475.00 \\
2.5 & 1427.97 & 1397.65 & 1357.87 & 1299.33 \\
\hline
\end{tabular}

\section{Conclusion}

The study revealed that for water cured samples at 28 days, the compressive will be within required standard if the kenaf replacement level does not exceed $1.0 \%$ while it should not exceed $1.5 \%$ for air curing at $1: 5$ cement mix ratio. The 1:10 cement mix samples however did not meet the [22] standard for $\mathrm{O}$ and $\mathrm{N}$ type mortar although the trend of compressive strength variation was similar to what was obtained in the 1:5 samples thus indicating that binder strength was inadequate. In conclusion information obtained from the study has revealed that kenaf reinforcement of mortar could offer a promising 'green' construction material which could potentially be used in a number of different structural and non-structural applications.

\section{References}

[1] Katale, D. P. and Adedeji, A. A. Investigation on the Use of Clayey Soil Mixed with Cow Dung to Produce Sustainable Bricks, Trends in Applied Sciences Research, 2014. 9 (8): 406-424.

[2] Akanni, P. O., Oke, A. E. and Omotilewa, O. J. Implications of Rising Cost of Building Materials in Lagos State Nigeria, SAGE Open 2014, pp. 1-7 DOI: 10.1177/2158244014561213

[3] Mansur, S. A., Abdul Hamid, A. R., and Yusof, N. A. Rising Trend in Construction Cost and Housing Price, Journal of Advanced Research in Business and Management Studies 2016, 3(1) pp.94-104,

[4] Osunade, J. A., and Fajobi, A. B. Some Engineering Properties Of Laterite/Cement Masonry Blocks Made With Hand - Operated Moulding Machine Granite Fine And Admixtures, Journal of Agricultural Engineering and Technology, 2000. 8: $44-50$.

[5] Mansur, S. A., Abdul Hamid, A. R., and Yusof, N. A. Rising Trend in Construction Cost and Housing Price, Journal of Advanced Research in Business and Management Studies 2016, 3(1) pp.94-104,

[6] Olanipekun, E. A., Olusola, K. O., and Ata, O. A Comparative Study of Concrete Properties using Coconut Shell and Palm Kernel Shell as Coarse Aggregates, Building and Environment, 2005. 41: $297-301$. 
[7] Lasis, F and J. A. Osunade. Laterized Concrete Masonry as an alternative in building and rural Infrastructures. Proceeding of International Conference on Structural Engineering. Ghana, Seam 2, 1990, pp. 151- 161 .

[8] Osunade, J. A.; and Ogundeko, O. F. Fibre Reinforcement As They Affect Shear and Tensile Strength of Laterized Concrete. International Journal of Housing Science and Application, 1992.

[9] Arumala, J. O. (2014). Kenaf Building Blocks. Proceedings of the 121st ASEE Annual Conference and Exposition. Pp 1-9.

[10] Bhutta, M. A. R., Nur Hafizah, A. K., Jamaludin, M. Y. Warid, M. H., Ismail, M., Azman, M. Strengthening Reinforced Concrete Beams Using Kenaf Fibre Reinforced Polymer Composite Laminates. Third International Conference on Sustainable Construction Materials and Technology. (2013) available at http://www.claisse.info/Proceedings.htm.

[11] Millogo, Y; Aubert, J; Hamard, E; Morel, J. (2015). How Properties of Kenaf Fibers from Burkina Faso Contribute to the Reinforcement of Earth Blocks. Materials, 8, 2332-2345.

[12] Hanisom, A.; and Ahmad, K. J. Properties of Eco-brick Manufactured Using Kenaf Fibre as Matrix, Global Illuminators Publishing Full Paper Proceeding MISG-2015, Vol. 1, pp. 13-20.

[13] Webber, C. L., Bhardwaj H. L., and Bledsoe V. K. Kenaf Production: Fiber, Feed, and Seed Reprinted from: Trends in new crops and new uses. J. Janick and A. Whipkey (eds). ASHS Press, Alexandria, VA. (2002).

[14] Kasthurba, A. K., K. R. Reddy and Reddy, D. V. Use of Laterite as a Sustainable Building Material in Developing Countries. International journal of earth sciences and engineering, 2014. 7(4): 1251-1258.
[15] Hanisom, A.; and Ahmad, K. J. Properties of Eco-brick Manufactured Using Kenaf Fibre as Matrix, Global Illuminators Publishing Full Paper Proceeding MISG-2015, Vol. 1, 13-20.

[16] Lasis, F. Utilisation of local materials in building construction in nigeria- studies on lateritic soils laterized concrete and sandcrete blocks. Proceedings of the international congress on housing, Valparaiso, Chile. (1985):

[17] Aguwa, J. I. Study of compressive strengths of laterite-cement mixes as a building material. Assumption University Journal of Technology. 2009. 13 (2): 114-120.

[18] Olofinnade, O. M., Ede, A. N., Ndambuki, J. M., and Olukanni, D. O. Effects of Different Curing Methods on the Strength Development of Concrete Containing Waste Glass as Substitute for Natural Aggregate Covenant Journal of Engineering Technology (CJET) 2017 1(1) pp. 1-17.

[19] ASTM C270. American Society for Testing and Materials Standard Specification for Mortar for Unit Masonry (ASTM C270 - 14a).

[20] Yalley, P. P. Strength and Durability Properties of Cow Dung Stabilised Earth Brick Civil and Environmental Research, 2013. 3(13): 117-125.

[21] Razali, M. K. and Yatim, J. M. Mechanical Properties of Kenaf Fibrous Mortar for Brickworks. Structure and Materials, 2016. 1: 280-292.

[22] ASTM C270. American Society for Testing and Materials Standard Specification for Mortar for Unit Masonry (ASTM C270 - 14a). 